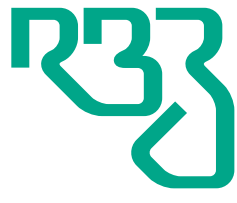

Revista

Brasileira de

Zootecnia

Brazilian Journal of Animal Science

ISSN 1806-9290

www.rbz.org.br

\section{Determination of nutrient and energy values of cottonseed meal supplemented or not with phytase and protease for broiler chicks}

\author{
Alcilene Maria Andrade Tavares-Samay ${ }^{1}$ (D), Wilson Moreira Dutra Junior ${ }^{2}$ iD, \\ Liliane Olímpio Palhares² (iD, Cláudia da Costa Lopes ${ }^{3 *}$ iD, Carlos Bôa-Viagem \\ Rabello² $^{2}$ iD, Andrew Henrique da Silva Cavalcanti Coelho² (iD \\ ${ }^{1}$ Instituto Federal de Educação, Ciência e Tecnologia de Pernambuco, Campus Belo Jardim, \\ Belo Jardim, PE, Brasil. \\ ${ }^{2}$ Universidade Federal Rural de Pernambuco, Departamento de Zootecnia, Recife, PE, Brasil. \\ ${ }^{3}$ Universidade Federal do Amazonas, Instituto de Ciências Sociais, Educação e Zootecnia, \\ Departamento de Zootecnia, Parintins, AM, Brasil.
}

*Corresponding author: cclway@yahoo.com.br

Received: September 25, 2018

Accepted: March 13, 2019

How to cite: Tavares-Samay, A. M. A.; Dutra Junior, W. M.; Palhares, L. O.; Lopes, C. C.; Rabello, C. B. V. and Coelho, A. H. S. C. 2019. Determination of nutrient and energy values of cottonseed meal supplemented or not with phytase and protease for broiler chicks. Revista Brasileira de Zootecnia 48:e20180142.

https://doi.org/10.1590/rbz4820180142

Copyright: This is an open access article distributed under the terms of the

Creative Commons Attribution License (http://creativecommons.org/licenses/by/4.0/), which permits unrestricted use, distribution, and reproduction in any medium, provided the original work is properly cited.

\begin{abstract}
The objective of this study was to determine the nutritional and energy compositions of cottonseed meal (CM), with or without enzyme supplementation, for broilers at different ages. A total of 672 male Cobb 500 chickens were distributed into four metabolism and ileal-digestibility trials. The experimental design was completely randomized, with four treatments and six replicates. The following treatments were tested: a corn- and soybean meal-based control diet without enzymes; control diet with enzyme addition; control diet with $25 \%$ replaced by CM; and control diet with enzyme addition and $25 \%$ replaced by $\mathrm{CM}$. The following variables were investigated: apparent metabolizable energy (AME); nitrogen-corrected AME (AMEn); apparent metabolizability coefficients of dry matter, gross energy, phosphorus, and calcium; apparent ileal digestibility coefficients of dry matter, crude protein, calcium, and phosphorus; and digestible protein of CM. Enzyme supplementation did not affect the energy values of CM. The average values obtained in the pre-starter, starter, grower, and finisher phases were 2,958; 2,554; 1,676, and 1,963 $\mathrm{kcal} \mathrm{kg}^{-1}$ for AME and 2,519; 2,$282 ; 1,423$, and $1,680 \mathrm{kcal} \mathrm{kg}^{-1}$ for AMEn, respectively. Enzyme addition improves the apparent digestibility coefficients of phosphorus and calcium of cottonseed meal in the grower phase. However, enzyme supplementation does not affect the ileal digestibility coefficients of these ingredients in broilers.
\end{abstract}

\title{
Introduction
}

Nutritionally efficient and economically viable diets for broilers are formulated on the basis of digestibility results, since the energy density of a diet directly interferes with animal performance (Brumano et al., 2006). Soybean meal is the most commonly used protein ingredient in poultry feeding; however, its price fluctuates largely due to climatic variables affecting its productivity and because it is widely consumed by humans.

For this reason, researchers are constantly investigating feedstuffs considered alternatives to poultry. One of such is cottonseed meal (CM), a byproduct of the cotton industry obtained after the oil-extraction step. On a global scale, it is the largest protein source available for animal feeding, after soybean meal 
only (USDA, 2016). However, the use of CM in poultry diets is limited because of its chemical variability, as it contains crude protein contents ranging from 29.98 to $39.21 \%$, crude fiber contents from 12.6 to 23.7\%, total phosphorus contents from 0.87 to $1.03 \%$, and lysine from 1.21 to $1.62 \%$ (Rostagno et al., 2017). The presence of gossypol, a toxic polyphenolic compound found in the cottonseed (Dalle Zotte et al., 2013) that reduces lysine utilization by broilers (Nagalakshmi et al., 2007), is another factor restricting its use.

One of the ways to maximize the utilization of these alternative ingredients by broilers is the addition of exogenous enzymes to their diet, which improve the utilization of nutrients, allowing to reduce levels of metabolizable energy and amino acids of the diets without negatively affecting animal performance. Phytases increase phosphorus availability, whereas proteases improve protein digestion. Furthermore, they allow for lesser environmental pollution due to the decreased excretion of nitrogen and phosphorus (P), since 77\% of the total P in CM is in phytate-P form (Selle and Ravindran, 2007).

When combined, these two enzymes can improve the utilization of CM by broilers, allowing for a reduction in the dietary inclusion of soybean meal. Considering the above-described, the present study was undertaken to determine the nutritional, energy, and amino acid compositions of cottonseed meal with or without phytase and protease supplementation. The apparent ileal digestibility coefficients of crude protein, calcium, and phosphorus in broilers at different ages were also evaluated.

\section{Material and Methods}

All experimental procedures were conducted in accordance with the recommendations of the local Ethics Committee (case no. 042/2013). The study took place in Recife, PE, Brazil (802'10" S and $34^{\circ} 95^{\prime} 39^{\prime \prime} \mathrm{W}, 18 \mathrm{~m}$ asl).

Four metabolism and ileal-digestibility trials were carried out consecutively, involving 672 male Cobb 500 chickens. This total corresponded to 240 chickens in the pre-starter phase (one to seven days), 192 in the starter phase (13 to 21 days), 144 in the grower phase ( 25 to 33 days), and 96 in the finisher phase ( 34 to 42 days).

Broilers were kept in three-floor batteries with cages $(1.00 \times 0.50 \times 0.50 \mathrm{~m})$ equipped with trough feeders and cup drinkers. A completely randomized design with four treatments and six replicates was adopted, totaling 24 experimental units in all phases.

The whole experiment lasted eight days, which consisted of four days dedicated to adaptation and four days for total excreta collection, except for the pre-starter phase, which was composed of three days of acclimation and four days of data collection. The last day of each phase was used for collection of ileal content. During each experimental period, the following air temperature and air relative humidity values were recorded in the pre-starter, starter, grower, and finisher phases: $31.5,30.3,29.1$, and $28.5^{\circ} \mathrm{C}$ and $58.3,68.4,63.8$, and $68.4 \%$, respectively.

The following treatments were examined in the study: a corn- and soybean meal-based control diet without enzymes; control diet with enzyme addition; control diet with $25 \%$ replaced by CM; and control diet with enzyme addition and $25 \%$ replaced by $\mathrm{CM}$. The exogenous enzymes used in the rations were supplemented with no nutritional reductions in the diets, following the manufacturer's instructions:

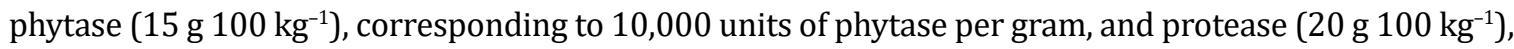
corresponding to 84,500 units of protease per gram.

The cottonseed meal used in this study was obtained after mechanical pressing. Before it was

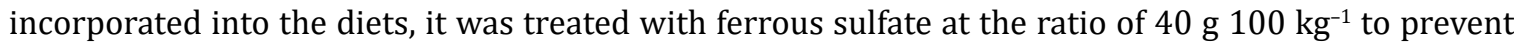
the negative effect of gossypol. The chemical and energy composition of CM (Table 1) was analyzed according to methodologies described by AOAC (2000). The free gossypol content in it was determined as described in method Ba 7-58 of the American Oil Chemical Society (AOCS, 2009), whereas its 
Table 1 - Chemical, energy, and amino acid compositions of cottonseed meal

\begin{tabular}{lclcc}
\hline Nutrient & Composition $\left(\mathrm{g} \mathrm{kg}^{-1}\right)$ & Amino acid & Total $\left(\mathrm{g} \mathrm{kg}^{-1}\right)$ & Digestibility $\left(\mathrm{g} \mathrm{kg}^{-1}\right)$ \\
\hline Dry matter & 945.8 & Arginine & 28.4 & 20.8 \\
Crude protein & 242.8 & Histidine & 6.9 & 5.0 \\
Ether extract & 79.4 & Isoleucine & 8.2 & 7.4 \\
Neutral detergent fiber & 435.6 & Leucine & 15.1 & 11.1 \\
Acid detergent fiber & 318.0 & Lysine & 10.7 & 7.8 \\
Mineral matter & 75.1 & Methionine & 3.7 & 2.8 \\
Calcium & 8.8 & Methionine + cystine & 8.1 & 5.5 \\
Phosphorus & 6.3 & Phenylalanine & 13.9 & 10.8 \\
Gross energy $\left(\mathrm{kcal} \mathrm{kg}^{-1}\right)$ & 4,614 & Threonine & 8.2 & 6.3 \\
Free gossypol & 0.479 & Valine & 11.4 & 8.6 \\
\hline
\end{tabular}

${ }^{1}$ Values estimated from the amino acid digestibility coefficients tabulated by Rostagno et al. (2017).

amino acid composition was analyzed by high-performance liquid chromatography (HPLC) through a P 6.1L AZURA ${ }^{\circledR}$ bomb.

The experimental diets (Table 2) were formulated to meet the nutritional requirements of broilers according to each rearing phase, following the recommendations of Rostagno et al. (2005). Water and feed were available ad libitum throughout the experimental period.

The total excreta collection method, described by Sibbald and Slinger (1963), was employed to determine the metabolizable energy value. Ferric oxide was used in the diets as a fecal marker, at the rate of $1 \%$. During the collection period, excreta were harvested daily, weighed, identified, and stored in a freezer at $-20^{\circ} \mathrm{C}$. At the end of the experimental period, they were thawed, homogenized, pre-dried in a forced-air oven at $55^{\circ} \mathrm{C}$ for $72 \mathrm{~h}$, ground, and sent to the laboratory.

Samples of excreta, ingredients, and diets were analyzed to determine the concentrations of dry matter (DM), nitrogen, P, and calcium (Ca) (AOAC, 2000). Gross energy (GE) was determined in a bomb calorimeter. Based on the obtained data, we determined the values of apparent metabolizable energy (AME) and nitrogen-corrected AME (AMEn), by employing equations proposed by Matterson et al. (1965), and calculated the apparent metabolizability coefficients of GE, DM, P, and Ca.

To determine apparent ileal digestibility, $1 \%$ of the chromic oxide $\left(\mathrm{Cr}_{2} \mathrm{O}_{3}\right)$ indicator was added to the experimental diets on the last four days of each experimental period, as described by Sakomura and Rostagno (2016).

On the 7th, 21st, 33rd, and 42nd days, $2 \mathrm{~h}$ before slaughter, broilers were stimulated to consume feed to ensure a larger amount of material to be collected. After this time, all broilers were slaughtered by cervical displacement, and the digesta content present in the ileum was harvested, identified, and stored in a freezer at $-20^{\circ} \mathrm{C}$. Subsequently, the samples were thawed and lyophilized for $24 \mathrm{~h}\left(-50^{\circ} \mathrm{C} ;-80 \mathrm{kPa}\right)$. Next, they were ground through a ball mill and analyzed in the laboratory for the concentrations of $\mathrm{DM}, \mathrm{CP}, \mathrm{Ca}$, $\mathrm{P}$, and chromium (Cr) (AOAC, 2000).

Based on the results of the analyses of diets and digesta, we determined the apparent ileal digestibility coefficients of DM, CP, Ca, and P, in addition to digestible protein, using the following formulae:

Indigestibility factor (IF):

$$
\text { IF = Diet indicator } / \text { Digesta indicator }
$$

Apparent digestibility coefficient of dry matter:

$$
\operatorname{ADCDM}(\%)=100-(\mathrm{IF} \times 100)
$$

Apparent digestibility coefficient of nutrient:

$$
\mathrm{ADC} \text { of nutrient }(\%)=\text { Nutrient diet }-(\text { nutrient digesta } \times \mathrm{IF}) / \text { nutrient diet } \times 100
$$


Digestible protein (DP):

$$
\mathrm{DP}=\mathrm{CP}(\text { diet } / \text { feed }) \times \mathrm{ADCCP}(\text { diet } / \text { feed }) / 100
$$

All the evaluated variables were subjected to analysis of variance and comparison of means by the test at the 5\% probability level, using SAS software (Statistical Analysis System, version 9.4).

Table 2 - Composition and nutritional values of experimental diets

\begin{tabular}{|c|c|c|c|c|c|c|c|c|}
\hline \multirow{3}{*}{ Item } & \multicolumn{8}{|c|}{ Experimental ration } \\
\hline & \multicolumn{2}{|c|}{ Pre-starter } & \multicolumn{2}{|c|}{ Starter } & \multicolumn{2}{|c|}{ Grower } & \multicolumn{2}{|c|}{ Finisher } \\
\hline & CD & CDE & CD & CDE & CD & $\mathrm{CDE}$ & CD & CDE \\
\hline \multicolumn{9}{|l|}{ Ingredient $\left(\mathrm{g} \mathrm{kg}^{-1}\right)$} \\
\hline Corn & 554.43 & 554.43 & 593.87 & 593.87 & 622.16 & 622.16 & 663.88 & 663.88 \\
\hline Soybean meal & 385.64 & 385.64 & 342.63 & 342.63 & 306.93 & 306.93 & 267.01 & 267.01 \\
\hline Dicalcium phosphate & 19.10 & 19.10 & 18.18 & 18.18 & 16.75 & 16.75 & 15.25 & 15.25 \\
\hline Limestone & 8.55 & 8.55 & 8.35 & 8.35 & 7.93 & 7.93 & 7.59 & 7.59 \\
\hline Soybean oil & 17.15 & 17.15 & 24.39 & 24.39 & 34.23 & 34.23 & 33.77 & 33.77 \\
\hline Salt & 4.56 & 4.56 & 4.45 & 4.45 & 4.24 & 4.24 & 4.03 & 4.03 \\
\hline DL-methionine & 3.25 & 3.25 & 2.38 & 2.38 & 2.19 & 2.19 & 2.17 & 2.17 \\
\hline L-lysine & 3.55 & 3.55 & 2.61 & 2.61 & 2.54 & 2.54 & 3.07 & 3.07 \\
\hline L-threonine & 1.42 & 1.42 & 0.79 & 0.79 & 0.68 & 0.68 & 0.88 & 0.88 \\
\hline Mineral $^{1}$ & 0.50 & 0.50 & 0.50 & 0.50 & 0.50 & 0.50 & 0.50 & 0.50 \\
\hline Vitamin $^{2}$ & 1.00 & 1.00 & 1.00 & 1.00 & 1.00 & 1.00 & 1.00 & 1.00 \\
\hline Choline chloride & 0.50 & 0.50 & 0.50 & 0.50 & 0.50 & 0.50 & 0.50 & 0.50 \\
\hline Inert $^{3}$ & 0.35 & 0.00 & 0.35 & 0.00 & 0.35 & 0.00 & 0.35 & 0.00 \\
\hline Phytase & 0.00 & 0.15 & 0.00 & 0.15 & 0.00 & 0.15 & 0.00 & 0.15 \\
\hline Protease & 0.00 & 0.20 & 0.00 & 0.20 & 0.00 & 0.20 & 0.00 & 0.20 \\
\hline Total & 1000.0 & 1000.0 & 1000.0 & 1000.0 & 1000.0 & 1000.0 & 1000.0 & 1000.0 \\
\hline \multicolumn{9}{|l|}{ Nutritional content (calculated) } \\
\hline Metabolizable energy $\left(\mathrm{kcal} \mathrm{kg}^{-1}\right)$ & \multicolumn{2}{|c|}{2,960} & \multicolumn{2}{|c|}{3,050} & \multicolumn{2}{|c|}{3,150} & \multicolumn{2}{|c|}{3,200} \\
\hline Crude protein $\left(\mathrm{g} \mathrm{kg}^{-1}\right)$ & \multicolumn{2}{|c|}{229.5} & \multicolumn{2}{|c|}{211.4} & \multicolumn{2}{|c|}{197.3} & \multicolumn{2}{|c|}{183.4} \\
\hline Calcium $\left(\mathrm{g} \mathrm{kg}^{-1}\right)$ & \multicolumn{2}{|c|}{9.42} & \multicolumn{2}{|c|}{8.99} & \multicolumn{2}{|c|}{8.37} & \multicolumn{2}{|c|}{7.75} \\
\hline Available phosphorus ( $\mathrm{g} \mathrm{kg}^{-1}$ ) & \multicolumn{2}{|c|}{4.71} & \multicolumn{2}{|c|}{4.49} & \multicolumn{2}{|c|}{4.18} & \multicolumn{2}{|c|}{3.86} \\
\hline Sodium $\left(\mathrm{g} \mathrm{kg}^{-1}\right)$ & \multicolumn{2}{|c|}{2.24} & & & & & & \\
\hline Chlorine $\left(\mathrm{g} \mathrm{kg}^{-1}\right)$ & & & & & & & & 6 \\
\hline Potassium $\left(\mathrm{g} \mathrm{kg}^{-1}\right)$ & & & & & & & & 1 \\
\hline Fat $\left(\mathrm{g} \mathrm{kg}^{-1}\right)$ & & & & & & & 60 & \\
\hline Linoleic acid $\left(\mathrm{g} \mathrm{kg}^{-1}\right)$ & & & & & & & & 84 \\
\hline Crude fiber $\left(\mathrm{g} \mathrm{kg}^{-1}\right)$ & & & & & & & & 75 \\
\hline Digestible amino acids ( $\mathrm{g} \mathrm{kg}^{-1}$ ) & & & & & & & & \\
\hline Methionine + cystine & & & & & & & & 55 \\
\hline Methionine & & & & & & & & 75 \\
\hline Lysine & & & & & & & & 48 \\
\hline Threonine & & & & & & & & 31 \\
\hline Tryptophan & & & & & & & & 2 \\
\hline Arginine & & & & & & & & 00 \\
\hline Valine & & & & & & & & 37 \\
\hline
\end{tabular}

$\mathrm{CD}$ - control diet without enzymes; CDE - control diet with enzyme addition.

${ }^{1}$ Level/kg of ration: Mn, 75,000 mg; Zn, 70,000 mg; Fe, 60,000 mg; Cu, 85,000 mg; I, 1500 mg; Co, $200 \mathrm{mg}$

${ }^{2}$ Level/kg of ration: vitamin A, 1,000,000 UI; vitamin B3, 2,000,000 UI; vitamin E, 20,000 mg; vitamin K3, $4000 \mathrm{mg}$; vitamin B1, $1880 \mathrm{mg}$ vitamin B2, $5000 \mathrm{mg}$; vitamin B6, $2000 \mathrm{mg}$; vitamin B12, $1000 \mathrm{mg}$; niacin, 30,000 mg; pantothenic acid, 13,500 mg; folic acid, 500 mg; selenium, $250 \mathrm{mg}$; antioxidant, $100,000 \mathrm{mg}$.

${ }^{3}$ Washed and sieved sand. 


\section{Results}

Phytase and protease addition in the pre-starter, starter, and finisher phases did not affect $(\mathrm{P}>0.05)$ the energy values or metabolizability coefficients of DM, GE, Ca, and P of cottonseed meal (Table 3). However, in the grower phase, the apparent metabolizability coefficients of $\mathrm{P}$ and Ca rose with the addition of enzymes, validating the efficiency of supplementation.

There were differences between the AME and AMEn values in the pre-starter, starter, grower, and finisher phases $\left(439,272,253\right.$, and $283 \mathrm{kcal} \mathrm{kg}^{-1}$, respectively). The AME values found in CM (Table 3) were higher than the AMEn values measured in the ingredient, suggesting that the nitrogen balance exhibited by the broilers was positive. In other words, there was retention of nitrogen derived from the ingredient for protein tissue deposition.

In the evaluation of $\mathrm{CM}$, with or without enzyme addition, on the apparent ileal digestibility coefficients of DM, CP, Ca, and P, or on digestible protein during all phases (Table 4), no effect $(\mathrm{P}>0.05)$ of enzyme supplementation was found on the utilization of the ingredient.

Table 3 - Apparent metabolizable energy (AME) values determined, nitrogen-corrected AME (AMEn), and apparent metabolizability coefficients of dry matter (AMCDM), gross energy (AMCGE), phosphorus (AMCP), and calcium (AMCCa) of cottonseed meal with or without enzymes in broiler diets

\begin{tabular}{|c|c|c|c|c|c|}
\hline & \multicolumn{3}{|c|}{ Cottonseed meal } & \multirow{2}{*}{$P$} & \multirow{2}{*}{ CV $(\%)$} \\
\hline & Without enzymes & With enzymes & Average & & \\
\hline \multicolumn{6}{|c|}{ Pre-starter (one to seven days) } \\
\hline AME (kcal kg-1) & 3,001 & 2,915 & 2,958 & NS & 2.88 \\
\hline AMEn $\left(\mathrm{kcal} \mathrm{kg}^{-1}\right)$ & 2,558 & 2,480 & 2,519 & NS & 3.30 \\
\hline AMCDM (\%) & 52.72 & 52.49 & 52.16 & NS & 7.81 \\
\hline AMCGE (\%) & 68.53 & 66.69 & 67.61 & NS & 3.76 \\
\hline AMCР (\%) & 15.06 & 15.56 & 15.31 & NS & 4.53 \\
\hline AMCCa (\%) & 15.06 & 15.26 & 15.16 & NS & 5.50 \\
\hline \multicolumn{6}{|c|}{ Starter (13 to 21 days) } \\
\hline $\operatorname{AME}\left(\mathrm{kcal} \mathrm{kg}^{-1}\right)$ & 2,722 & 2,386 & 2,554 & NS & 12.87 \\
\hline AMEn (kcal kg-1) & 2,356 & 2,208 & 2,282 & NS & 9.43 \\
\hline $\operatorname{AMCDM}(\%)$ & 47.15 & 45.68 & 46.42 & NS & 8.19 \\
\hline AMCGE (\%) & 64.90 & 60.21 & 62.55 & NS & 8.86 \\
\hline AMCP (\%) & 12.59 & 13.00 & 12.80 & NS & 3.81 \\
\hline AMCCa (\%) & 16.53 & 17.02 & 16.78 & NS & 3.32 \\
\hline \multicolumn{6}{|c|}{ Grower (25 to 33 days) } \\
\hline $\operatorname{AME}\left(\mathrm{kcal} \mathrm{kg}^{-1}\right)$ & 1,580 & 1,771 & 1,676 & NS & 12.06 \\
\hline AMEn (kcal kg-1) & 1,384 & 1,461 & 1,423 & NS & 13.20 \\
\hline $\operatorname{AMCDM}(\%)$ & 25.57 & 28.56 & 27.07 & NS & 12.09 \\
\hline AMCGE (\%) & 37.65 & 39.60 & 39.62 & NS & 6.77 \\
\hline AMCP (\%) & $12.18 \mathrm{~b}$ & $13.81 \mathrm{a}$ & 13.00 & 0.002 & 5.51 \\
\hline AMCCa (\%) & $14.27 \mathrm{~b}$ & $16.11 \mathrm{a}$ & 15.19 & 0.002 & 4.96 \\
\hline \multicolumn{6}{|c|}{ Finisher ( 34 to 42 days) } \\
\hline AME (kcal kg-1) & 2,101 & 1,825 & 1,963 & NS & 12.44 \\
\hline AMEn (kcal kg-1) & 1,798 & 1,562 & 1,680 & NS & 12.97 \\
\hline $\operatorname{AMCDM}(\%)$ & 37.25 & 38.51 & 37.88 & NS & 12.57 \\
\hline AMCGE (\%) & 49.66 & 42.44 & 46.05 & NS & 12.84 \\
\hline AMCP (\%) & 9.58 & 10.25 & 9.92 & NS & 8.31 \\
\hline AMCСа (\%) & 7.71 & 8.556 & 8.13 & NS & 9.67 \\
\hline
\end{tabular}

P - probability; CV; coefficient of variation; NS - not significant.

Average values followed by the same letter in the row do not differ significantly by the t test at the $5 \%$ probability. 
Table 4 - Apparent ileal digestibility coefficients of dry matter (ADCDM), crude protein (ADCCP), calcium (ADCCa), and phosphorus (ADCP) and digestible protein (DP) values of cottonseed meal with or without enzymes

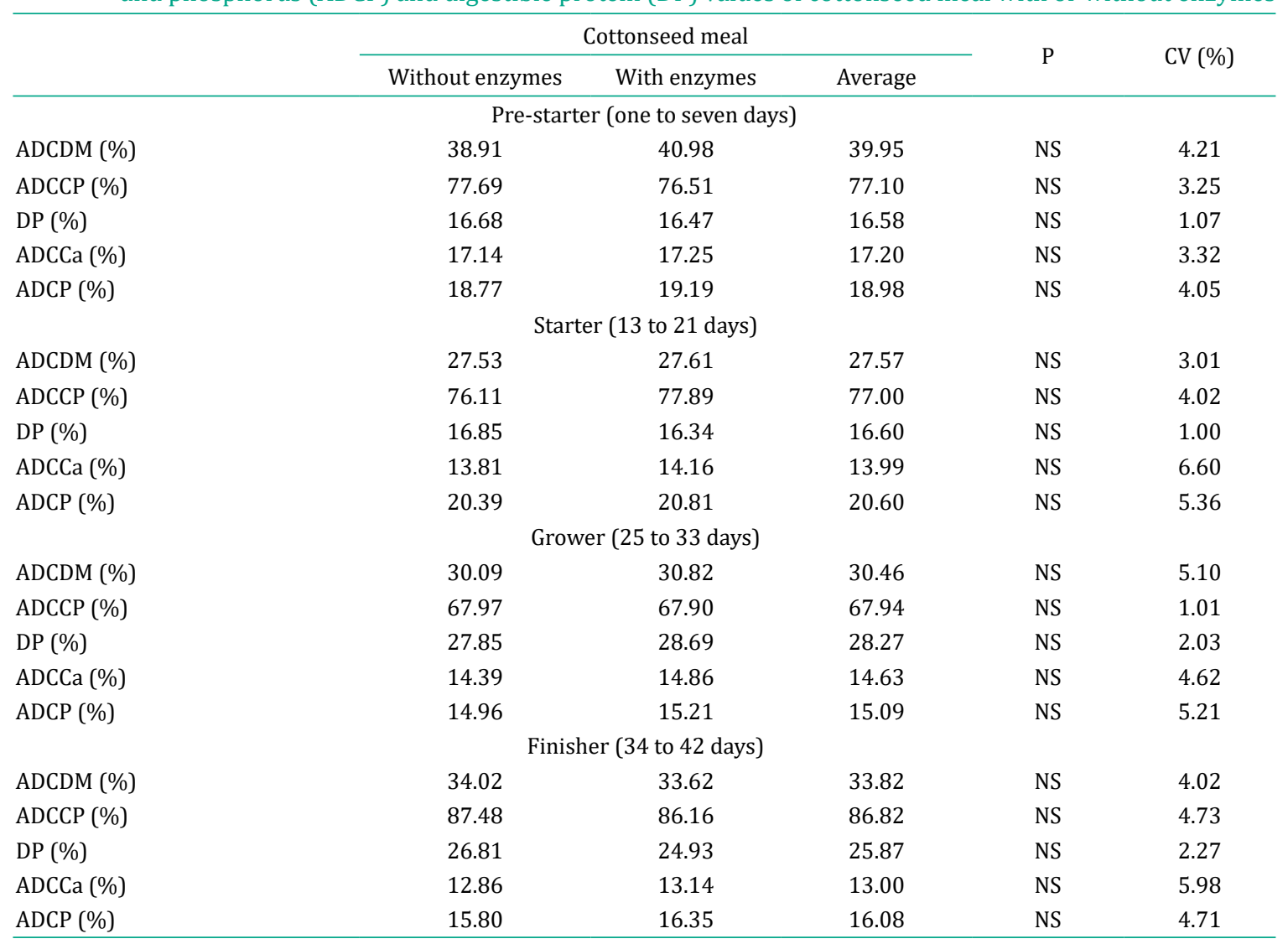

P - probability; CV; coefficient of variation; NS - not significant.

\section{Discussion}

The statistical insignificance of the metabolizable energy values in CM (Table 3) in the pre-starter, starter, and finisher phases showed that enzyme supplementation without nutritional reductions in the diet was not efficient with respect to availability of some nutrients and energy of the feedstuffs.

Sheehan (2011) stated that enzymatic reactions follow the principle that the product of an enzymatic reaction is the result of the interaction between enzyme and substrate. This fact could be explained by the inadequate conditions for the activity of enzymes in the gastrointestinal tract of broilers, which is possibly assumed due to the insufficient enzyme-substrate bond on the surface of the intestinal mucosa. This is caused by the immaturity of that compartment in terms of morphological and physiological development, especially during the initial life stages, due to the short residence time of the digesta in the digestive tract of these animals. Svihus (2014) explains that the passage rate of the digesta may influence the utilization of the diet, alter the intake capacity of a feedstuff, and determine the time during which nutrients will be exposed to the action of digestive enzymes and intestinal absorptive surface.

Additionally, there are physiological limits imposed by the digestive tract conditions in response to enzyme activities. Enzymes may not be able to overcome the physiological conditions of poultry. These barriers are related to $\mathrm{pH}$ and the residence time of the feed in the digestive tract, which may even antagonize digestive enzymes in those animals (Cowieson, 2010).

For this reason, McCleary (2001) and Ravindran (2013) declared that the enzymatic activity in poultry diets should be sufficiently high to ensure its effect, given the very physiology of broilers. Cardoso et al. (2011) also highlighted the need for further research aiming to clarify uncertainties regarding enzymatic activity and its mechanism of action. 
The AME values were higher than the AMEn values determined in CM (Table 3), indicating that the nitrogen balance shown by the broilers was positive, i.e., there was retention of the nitrogen derived from the ingredient for protein tissue deposition. According to Generoso et al. (2008), this is more perceptible when correction is made for endogenous and metabolic losses. Those authors also stressed that the retained-nitrogen value in broilers fed ad libitum is greater than zero, making the AME higher than the AMEn values.

In the first two phases, the average AMEn values $\left(2,519\right.$ and 2,282 $\left.\mathrm{kcal} \mathrm{kg}^{-1}\right)$ were above the $1,666 \mathrm{kcal} \mathrm{kg}^{-1}$ (as-is basis) tabulated by Rostagno et al. (2017). However, they are within the range of 1,901 to 2,811 kcal kg-1 recommended by Nagalakshmi et al. (2007). For the grower and finisher phases, in turn, Generoso et al. (2008) reported variations in the energy values of CM from 1,625 to 1,786 kcal kg-1 for AME and 1,605 to $1,734 \mathrm{kcal} \mathrm{kg}^{-1}$ for AMEn, which are similar to those obtained in the present study.

Overall, the energy values of CM, mainly in the initial phases, were higher than those obtained in the grower and finisher phases even without enzyme addition. This fact emphasizes the importance of analyzing the development of organs in young broilers, since little research has been done on the absorptive capacity of the small intestine of broilers during the post-hatching period. Longo et al. (2005) stated that variations found in energy values indicate that the metabolic characteristics of each phase of broiler development can affect the energy value of feedstuffs and, consequently, alter the metabolizable energy value provided in the diet.

In the grower phase ( 25 to 33 days of age), enzyme supplementation provided better utilization of $\mathrm{P}$ and $\mathrm{Ca}$ in $\mathrm{CM}$, as can be observed by the 13.3 and $12.9 \%$ increase in the digestibility coefficients of $\mathrm{P}$ and $\mathrm{Ca}$, respectively, when enzyme supplementation was provided. This increased digestibility may be associated with supplementation with the phytase enzyme. Phytase enables the degradation of the phytic acid present in the plants, acting on the release of part of the fixed phosphorus and other minerals found available from the formation of insoluble complexes in the form of chelates with magnesium, zinc, and copper cations. As a result, the solubility and digestibility of these nutrients is increased (Selle and Ravindran, 2007; Singh and Satyanarayana, 2011; Gupta et al., 2013), contributing to a reduction in their excretion into the environment.

No significant differences were observed in the ileal digestibility coefficients during the pre-starter, starter, and finisher phases (Table 4). In this regard, it can be observed that the effect of enzymes, especially phytase, on the ileal digestibility and utilization of protein has been inconsistent, with highly conflicting information (Kong and Adeola, 2011). However, there are positive reports about the use of phytases on the digestibility of protein, amino acids, and phosphorus in broiler diets, such as those found by Cowieson et al. (2017), He et al. (2017), and Zouaoui et al. (2018).

The mechanism of action of protease on the ileal digestibility of protein may be considered dependent on the quality of dietary protein, since protein digestibility is benefited when protease is included in corn- and soybean meal-based diets (He et al., 2017). In the current experimental conditions, imbalanced diets were used to evaluate one ingredient with antinutritional factors. According to Murugesan et al. (2014), higher concentrations of protease or its association with carbohydrates might provide an improvement in protein digestibility.

Studies involving protease alone; enzyme complexes containing phytase, xylanase, amylase, and proteases (Barbosa et al., 2014); or even enzyme complexes containing proteases and phytases (Murugesan et al., 2014) showed improvements in the ileal digestibility of DM, CP, and minerals. However, Kong and Adeola (2011) found no additional effect of enzymes on the ileal digestibility of nutrients in broilers.

According to Barbosa et al. (2014), enzyme supplementation in diets with adequate nutritional levels does not lead to increased nutrient digestibility. Nevertheless, when this supplementation is performed along with a reduction of dietary nutritional levels, digestibility coefficients improve. The supplementation strategy used in this study (without reductions in the nutritional levels of the diet) was possibly responsible for the lack of effects on the digestibility of the evaluated nutrients.

R. Bras. Zootec., 48:e20180142, 2019 
In view of the results obtained in this study, further research should be undertaken to better examine the utilization of CM in broiler diets involving enzyme supplementation with reductions of dietary nutritional levels and considering the physiological development of the digestive tract of broilers at different ages.

\section{Conclusions}

Enzyme supplementation does not affect the energy values or the ileal digestibility coefficients of cottonseed meal. However, the enzyme rather increases the apparent digestibility coefficients of phosphorus and calcium during the grower phase of broilers, being able to provide less excretion of these nutrients in the environment.

\section{Acknowledgments}

The authors thank the Instituto Nacional de Ciência e Tecnologia de Ciência Animal (INCT-CA), Coordenação de Aperfeiçoamento de Pessoal de Nível Superior (CAPES), Conselho Nacional de Desenvolvimento Científico e Tecnológico (CNPq), and Universidade Federal Rural de Pernambuco for the research funds.

\section{References}

AOAC - Association of Official Analysis Chemists. 2000. Official methods of analysis. 17th ed. AOAC International, Arlington, VA, USA.

AOCS - American Oil Chemical Society. 2009. Official methods and recomended pratices of the American oil Chemists Society. 6th ed. Washington, DC.

Barbosa, N. A. A.; Bonato, M. A.; Sakomura, N. K.; Dourado, L. R. B.; Fernandes, J. B. K. and Kawauchi, I. M. 2014. Digestibilidade ileal de frangos de corte alimentados com dietas suplementadas com enzimas exógenas. Comunicata Scientiae 5:361-369.

Brumano, G.; Gomes, P. C.; Albino, L. F. T.; Rostagno, H. S.; Generoso, R. A. R. and Schmidt, M. 2006. Composição química e valores de energia metabolizável de alimentos protéicos determinados com frangos de corte em diferentes idades. Revista Brasileira de Zootecnia 35:2297-2302. https://doi.org/10.1590/S1516-35982006000800014

Cardoso, D. M.; Maciel, M. P.; Passos, D. P.; Silva, F. V.; Reis, S. T. and Aiura, F. S. 2011. Efeito do uso de complexo enzimático em rações para frangos de corte. Archivos de Zootecnia 60:1053-1064. https://doi.org/10.4321/S000405922011000400021

Cowieson, A. J. 2010. Strategic selection of exogenous enzymes for corn/soy-based poultry diets. Journal of Poultry Science 47:1-7. https://doi.org/10.2141/jpsa.009045

Cowieson, A.; Ruckebusch, J.-P.; Sorbara, J. O. B.; Wilson, J. W.; Guggenbuhl, P. and Roos, F. F. 2017. A systematic view on the effect of phytase on ileal amino acid digestibility in broilers. Animal Feed Science and Technology 225:182-194. https://doi.org/10.1016/j.anifeedsci.2017.01.008

Dalle Zotte, A.; Brand, T. S.; Hoffman, L. C.; Schoon, K.; Cullere, M. and Swart, R. 2013. Effect of cottonseed oilcake inclusion on ostrich growth performance and meat chemical composition. Meat Science 93:194-200. https://doi.org/10.1016/j. meatsci.2012.08.027

Generoso, R. A. R.; Gomes, P. C.; Rostagno, H. S.; Albino, L. F. T.; Barreto, S. L. T. and Brumano, G. 2008. Composição química e energética de alguns alimentos para frangos de corte em duas idades. Revista Brasileira de Zootecnia 37:1251-1256. https://doi.org/10.1590/S1516-35982008000700016

Gupta, R. K.; Gangoliya, S. S. and Singh, N. K. 2013. Reduction of phytic acid and enhancement of bioavailable micronutrients in food grains. Journal of Food Science and Technology 52:676-684. https://doi.org/10.1007/s13197-013-0978-y

He, S.; Medrano, R. F.; Yu, Q.; Cai, Y.; Dai, Q. and He, J. 2017. Effect of a microbial phytase on growth performance, plasma parameters and apparent ileal amino acid digestibility in Youxian Sheldrake fed a low-phosphorus corn-soybean diet. Asian-Australasian Journal of Animal Sciences 30:1442-1449.

Kong, C. and Adeola, O. 2011. Protein utilization and amino acid digestibility of canola meal in response to phytase in broiler chickens. Poultry Science 90:1508-1515. https://doi.org/10.3382/ps.2011-01363

Longo, F. A.; Menten, J. F. M.; Pedroso, A. A.; Figueiredo, A. N.; Racanicci, A. M. C.; Gaiotto, J. B. and Sorbara, J. O. B. 2005. Carboidratos na dieta pré-inicial de frangos de corte. Revista Brasileira de Zootecnia 34:123-133. https://doi. org/10.1590/S1516-35982005000100016 
Matterson, L. D.; Potter, L. M.; Stutz, M. W. and Singsen E. P. 1965. The metabolizable energy of feed ingredients for chickens. Agricultural Experimental Station Research Report 7:3-11.

McCleary, B. V. 2001. Analysis of feed enzymes. p.85-108. In: Enzyme in farm animal nutrition. Bedford, M. R. and Partridge, G. G., eds. London, UK.

Murugesan, G. R.; Romero, L. F. and Persia, M. E. 2014. Effects of protease, phytase and a Bacillus sp. direct-fed microbial on nutrient and energy digestibility, ileal brush border digestive enzyme activity and cecal short-chain fatty acid concentration in broiler chickens. PloS ONE 9:e101888. https://doi.org/10.1371/journal.pone.0101888

Nagalakshmi, D.; Rao, S. V. R.; Panda, A. K. and Sastry, V. R. B. 2007. Cottonseed meal in diets poultry: a review. Journal of Poultry Science 44:119-134. https://doi.org/10.2141/jpsa.44.119

Ravindran, V. 2013. Feed enzymes: The science, practice, and metabolic realities. The Journal of Applied Poultry Research 22:628-636. https://doi.org/10.3382/japr.2013-00739

Rostagno, H. S.; Albino, L. F. T.; Donzele, J. L.; Gomes, P. C.; Oliveira, R. F.; Lopes, D. C.; Ferreira, A. S. and Barreto, S. L. T. 2005. Tabela brasileira para aves e suínos. Composição de alimentos e exigências nutricionais. 2.ed. Universidade Federal de Viçosa, Viçosa, MG.

Rostagno, H. S.; Albino, L. F. T.; Hannas, M. I.; Donzele, J. L.; Sakomura, N. K.; Perazzo, F. G.; Saraiva, A.; Teixeira, M. V.; Rodrigues, P. B.; Oliveira, R. F.; Barreto, S. L. T. and Brito, C. 0. 2017. Tabelas brasileiras para aves e suínos: composição de alimentos e exigências nutricionais. 4.ed. Departamento de Zootecnia, Universidade Federal de Viçosa, Viçosa, MG.

Sakomura, N. K. and Rostagno, H. S. 2016. Metodologias de pesquisa em nutrição de monogástrico. 2.ed. FUNEP, Jaboticabal.

Selle, P. H. and Ravindran, V. 2007. Microbial phytase in poultry nutrition. Animal Feed Science and Technology 135:1-41. https://doi.org/10.1016/j.anifeedsci.2006.06.010

Sheehan, N. 2011. Analysis of enzymes, principles and problems: developments in enzymes analysis. p.260-272. In: Enzymes in farm animal nutrition. 2nd ed. Bedford, M. R. and Partridge, G. G., eds. London.

Sibbald, I. R. and Slinger, S. J. 1963. A biological assay for metabolizable energy in poultry feed ingredients together with findings which demonstrate some of the problems associated with the evaluation of fats. Poultry Science 42:313-325.

Singh, B. and Satyanarayana, T. 2011. Microbial phytases in phosphorus acquisition and plant growth promotion. Physiology and Molecular Biology of Plants 17:93-103. https://doi.org/10.1007/s12298-011-0062-x

Svihus, B. 2014. Function of the digestive system. Journal of Applied Poultry Research 23:306-314.

USDA - United States Department of Agriculture. National Agricultural Statistics Service. 2016. History of soybean crushing. U.S. Government Printing Office, Washington. Available at: <bookstore.gpo.gov>. Accessed on: Jan. $24,2018$.

Zouaoui, M.; Létourneau-Montminy, M. P. and Guay, F. 2018. Effect of phytase on amino acid digestibility in pig: A metaanalysis. Animal Feed Science and Technology 238:18-28. https://doi.org/10.1016/j.anifeedsci.2018.01.019 